\title{
Executive incentive pay strategies in entrepreneurial UK initial public offering companies: an empirical study
}

\author{
Deborah Allcock and Christopher Pass
}

\author{
Deborah Allcock is a \\ Doctoral Researcher at the \\ University of Bradford \\ School of Management, \\ Bradford, UK. \\ Christopher Pass is Reader \\ in Industrial Economics at \\ the University of Bradford \\ School of Management, \\ Bradford, UK.
}

\begin{abstract}
Purpose - The purpose of this paper is to use a sample of UK entrepreneurial initial public offering (IPO) companies to investigate whether they change their compensation strategies as they undertake the crucial transformation of the business from private to public status.

Design/methodology/approach - The paper uses the agency perspective to underpin an examination of the changes within the compensation packages of companies at the stage of the initial public offering, particularly with regard to the use of executive director incentive schemes, and compares this to "best practice" guidelines issued within the UK.

Findings - The paper discovers that even though incentive schemes are adopted, the majority are unconditional and requiring only an improvement in share price and the executive to remain employed in order for gains to be made. The general finding is that before IPO most companies did not have an incentive pay scheme in place, and those that did, operated unconditional option schemes. However, after IPO most companies introduced an incentive pay scheme, but the majority were unconditional rather than conditional (i.e. schemes requiring executives to meet pre-determined performance criteria - as recommended by "best practice" guidelines).

Originality/value - The paper exposes that, contrary to "best practice" guidelines and regulations, many of these schemes reward executives unconditionally with the only factor being them remaining in employment over the vesting period. Despite "best practice" and regulations, firms still appear to be defensive and protect the executives from rigorous scrutiny by shareholders.
\end{abstract}

Keywords Chief executives, Incentive schemes, Remuneration, Share options, Corporate governance, United Kingdom

Paper type Research paper

\section{Introduction}

An initial public offering (IPO) involves a firm, previously "private" obtaining a stock exchange listing and issuing its shares to outside shareholders, thereby becoming "public". Their crucial transformation from private to public status requires companies to take due note of various corporate governance matters, particularly the Combined Code requirements and "best practice" recommendations. The flotation of the company often leads to them being confronted by the "principal-agent" concern: how to reconcile the interests of incumbent managers and executive directors (as "agents") with those of the company's ultimate owners - the shareholders (as "principals") (Jensen and Meckling, 1976). "Best practice" guidelines suggest that appropriate mechanisms need to be put in place to motivate directors to align their own interests more closely with the shareholders, thus ensuring goal congruence (ABI, 1994, 1993). Incentive schemes for executive directors have been recommended as the key way to help overcome agency problems (Beatty and Zajac, 1994; Fama, 1980; Fama and Jensen, 1983; Murphy, 1985). In response to this and in order to recruit and retain competent executives, companies within the UK now design compensation strategies to incorporate long-term incentives (Conyon, 2000; Conyon et al., 2000). These compensation strategies involve the use of two main types of incentives, 
namely the executive share option scheme (ESOS) and the long-term incentive plan (LTIP). To assist companies in devising suitable schemes which align the interests of executives and shareholders the Greenbury Committee Report (1995) and the Association of British Insurers have proposed "best practice" guidelines (ABI, 2002, 1994, 1993, 1999, 1995 (Amended June 1999)). These guidelines recommend companies adopt conditional incentive schemes, which incorporate predetermined performance criteria, which must be met before option and LTIP grants can vest (see below, section on performance evaluation).

This paper presents an empirical study of the compensation arrangements for a sample of UK entrepreneurial IPO companies prior to the IPO and after the IPO to identify changes in their executive incentive scheme arrangements. It uses the principal-agent perspective to underpin the examination of the changes within the compensation packages of these companies at the stage of the initial public offering. It shows that, in line with agency predictions, changes do occur that can be associated with progressive governance and attempts to begin good practice at the time of going public.

\section{Background}

The IPO company provides researchers with a unique opportunity to examine executive compensation. The founder, who remains in control of the company at the time of IPO must begin the process of a transfer in managerial direction to a more open, professional management. This involves the consideration of a variety of issues and in particular corporate governance. In June 1998, the London Stock Exchange published the Principles of Good Governance and Code of Best Practice ("The Combined Code") which embraces the work of Cadbury (1992), Greenbury (1995) and Hampel (1998) and became effective in respect of accounting periods on or after 31 December 1998. Thus at the time of the offering it is vital to show good corporate governance practices. The outcome of this process leads directly to a dilution of ownership from the founders with a transfer to outside investors. As a result, agency theory can adequately underpin much of the governance research completed to date and indeed this research. The uniqueness of the IPO is provided by the fact that that the public have the first opportunity to examine thoroughly company specific information and it will be the first of many times that the company announces to future investors the compensation packages of the executive directors (Certo et al., 2001).

Classic agency theory shows a relationship where the owners (principals) of modern companies, namely the shareholders, delegate the management of the company to hired persons (agents) (Fama, 1980; Jensen and Meckling, 1976). These hired persons take the form of management and in particular the higher echelons of company management, i.e. the board of directors. The separation of ownership from control leads to a position where there is imperfect information between the principals and agents. These asymmetries of information show that the agent has increasing insider knowledge as compared with the more disadvantaged principal. This leaves room for self-serving opportunist behaviour by the agent (Berle and Means, 1932). Agency theory then attempts to reconcile this by encouraging the use of contracts, which encourage the agent to perform more in line with the wishes of the principal. The costs incurred by these prescriptive contracts are known as "agency costs".

Agency costs are minimised where the principal has complete knowledge over the actions of the agent, and as such corporate governance by way of monitoring and incentive alignment is not seen to be an issue here. However, when there is not complete information, outcome based contracts for the executives are desirable and governance issues such as monitoring and incentive alignment should be an integral part of such contracts (Fama and Jensen, 1983). Indeed, "corporations can and should increase their control over top managers by increasing the use of managerial incentives and monitoring by the board of directors" (Zajac and Westphal, 1994).

In the case of IPOs, as we show below, the transition from private to public status requires companies, now that they have widened their shareholder base, to consider either revising

VOL. 6 NO. 22006 | CORPORATE GOVERNANCE | PAGE 149 
their existing executive incentive schemes or to introduce such a scheme for the first time in order to adjust to the new situation confronting them.

\section{The provision of incentive-based compensation}

Executive compensation packages have been increasingly used as a strategic tool to attract, retain and motive key employees in an increasingly global labour market (Conyon, 2000). In the UK the typical executive package as seen within the range of mature publicly quoted companies, will comprise a base salary and benefits (such as a company car,) an annual bonus (which is often considered as short-term incentive remuneration) and a long-term incentive component, typically in the form of share options or long-term incentive plans (Conyon et al., 2000; Pass, 2003: Pass et al., 2000).

The executives of the IPO company have the challenging task of both making compensation packages attractive to executives and showing structures are in place to motive these executives to provide shareholder value. As such incentive schemes and monitoring are essential and can be seen as a mechanism to alleviate agency problems (Berkema et al., 1997; Hermlain and Weisbach, 1991; Murphy, 1985). This will aid to promote investor confidence at the time of the IPO and promote confidence in the company's future development and success.

Thus investors in the IPO company, whist investing at a time of uncertainty, are likely to value this signal as a positive corporate governance strategy that will effectively align the actions of the executives to those required by the shareholders.

IPO company compensation packages for executive directors tend to mirror those employed by long-established mature companies. The base salary and benefits can be deemed as the foundations of the salary package. A short-term, annual bonus provides some form of performance related risk, but this is only judged on (as a rule) the previous 12 months business figures (within the context of the IPO company, this is often related to, and paid out upon, the successful flotation of the company. Thus for many IPO executives this provides a short-term remuneration boost simply from the fact that the company has floated).

Long-term incentive strategies take two main forms, namely the ESOS and the LTIP. ESOSs and LTIPs involve the periodic grant/award of a specified number of shares in the company to the executive, which can be exercised/vested at some future date. Option and LTIP grants are commonly awarded annually and the maximum number allocated is usually linked to the value of the executives' basic salary.

The standard UK executive share option scheme provides the executive with the right (but not the obligation) to purchase shares at a fixed predetermined price (the "exercise" or "strike" price) following some specified period time (usually after a minimum period of three years). These schemes have been categorised as to those that have no specific performance targets attached, referred to from now on as "unconditional" schemes, and those with specific pre-determined performance target requirements in order for the share options to vest ("conditional" schemes). In the case of unconditional schemes there are no pre-determined performance requirements built in. The executive "gains" if the market price of the company's shares at the time of vesting is greater than the "exercise" price. However, most modern option schemes are conditional and have pre-determined performance criteria attached thus preventing the executive from exercising their right to purchase until such performance criteria are met (the section on "Performance evaluation" below discusses this issue in detail).

Long-term incentive plans are similar to conditional options schemes in terms of their general grant procedures, the specification of predetermined performance criteria and minimum vesting requirement. Unlike option schemes, however, LTIP awards vest at "zero price" (i.e. at no cost to the executive).

PAGE $150 \mid$ CORPORATE GOVERNANCE $\mid$ VOL. 6 NO. 22006 
Scrutiny of the prospectus documents shows that either just prior to the IPO or at the point of the IPO, remuneration committees are established and are comprised predominately of non-executive directors. Companies typically take this significant time of the IPO to either implement an executive incentive scheme for the first time or to adapt existing ones. A priori it is important that an IPO company should demonstrate that it is prepared to put in place compensation packages which encourages executives to promote shareholder value in order to encourage potential investors to subscribe to the flotation of the company.

\section{Data and results}

The data sample used in this study comprises a unique data set of UK initial public offering companies that have entrepreneurial founders on the boards of directors at the time of flotation. The data in this paper reports the results of a pilot study covering just one year from a larger sample of UK IPO companies. The listings for the main study and this pilot, have both been sourced from both the London Stock Exchange New Issues Listing and information from the Market Information \& Analysis section which hold historical fact sheets for all issues from 1998, (including companies issuing additional shares, re-admissions and transfers between markets). Lists have been merged and cross-referenced to enable a unique complete list of all issues and a list of IPO companies to be obtained.

Using IPO companies may have significant advantages in order to test the principal-agent relationship due to the dilution of ownership at the IPO. Caution must be observed though as at the time of the IPO, particularly with companies that have strong entrepreneurial ownership dispersion may be less than other IPO flotations where no founders have ownership. Indeed Baker and Gompers (2003) warn that at the time of the IPO companies may be more likely to have optimal governance and incentive structures compared to more established companies due to this very point.

The companies within the pilot study that provide the data sample have been collected from those floated on the London Stock Exchange (Main market and the TechMark) and the Alternative Investment Market (AIM) between the period of 1 January 2001 and 31 December 2001. For the given period, the London Stock Exchange lists show us that 150 companies were floated as initial public offerings. The IPO prospectuses for all 150 companies were obtained. These were predominately sourced via subscription to Thomson Research, which provides a comprehensive coverage of company filings for publicly quoted UK companies. Missing prospectuses were obtained either via company web sites, or by telephone/written request to the companies or their advisors whichever was deemed more appropriate. The Application for Listing or prospectus was examined with particular emphasis given to the section detailing the history and founders of the company. Any companies that were unit or investment trust were excluded from the sample first, then those deemed to involve a de-merger, merger or acquisition, corporate spin off, equity carve outs, reorganisations, or could be considered as solely acquisition vehicles were also excluded. This resulted in 63 companies who clearly demonstrated that they had been developed via the entrepreneurial process with entrepreneurial founders and those founders were serving as directors at the time of the flotation. The transition from entrepreneur founder/owner of the company to a more dispersed ownership structure gives clear grounds for change in corporate governance, and it is these changes that result in agency problems arising that can then be further examined. The IPO company provides an ideal setting to further examine the impact of this change on incentive pay strategies.

The data reported below have been complied from the information contained in the prospectuses of the 63 companies and published in pursuance of their IPO in 2001. Typically, an IPO prospectus provided details of relevant company information (trading history, financial record, executive directors etc.) including also details of compensation packages for directors. Examination of the 63 company prospectuses indicated that 33 companies at IPO either continued or adopted an "unconditional" incentive pay scheme and 26 companies either continued or adopted a "conditional" scheme at IPO. Of those 26 companies operating a conditional scheme 17 companies disclosed details of the 
performance criteria of their schemes but nine companies did not (see performance measures table below and the Appendix). The lack of transparency in the latter case was, as we argue below, a matter of concern. In 2002, The Directors Remuneration Regulation was passed by the Government, which requires companies to disclose details of their incentive schemes (The Directors' Remuneration Report Regulations 2002, 2002). However, as yet none of the nine companies have conformed, but in most cases their latest (2003) Annual Reports indicate that they will do so in the near future. Also some companies currently operating "unconditional" schemes have indicated that they will consider making their schemes "conditional". The general consensus is that it is "early days" and that the appropriate time for review/change of existing incentive arrangements is after the completion of the first post-IPO vesting cycle (for these nine companies this is three years), i.e. in 2004.

From the initial investigations of the 63 companies, 58 (92 per cent) had established remuneration committees. There were no remuneration committees that were comprised solely of executive directors but by contrast 39 of the 58 remuneration committees comprised solely non executive directors, 15 remuneration committees comprised of both executive and non executive directors and 4 merely stated the presence of a remuneration committee but gave no further details as to which members of the board sat on the committee.

The establishment of remuneration committees holds no surprises and indeed this means that for the most part they comply with the recommendations of Greenbury (1995) and Hampel (1998a, b).

\section{Pre IPO incentive pay schemes}

Table I shows the overall situation with regards to incentive pay for the sample firms prior to the IPO. Pre IPO, 22 (35 per cent) of the 63 companies had incentive pay schemes in place that provided long-term rewards. Table II indicates that of the 22 companies with incentive pay pre IPO only three had conditional schemes operating, whilst the vast majority (86 per cent) of the schemes operated were unconditional.

The high overall incidence of "no" incentive pay scheme and the preponderance of unconditional incentive schemes pre IPO is in accordance with agency theory. In these cases the principal-agent "problem" is either non-existent or minimal since the founding entrepreneur is the owner of the company and also the main executive director, i.e. there is no fundamental separation of ownership and control.

However, as agency theory predicts, the dilution of ownership and control which occurs when a business changes from "private" to "public" and takes on a wider "outside" shareholder base necessitates the company to consider the relationship between

\section{Table I Presence of incentive pay pre IPO}

\section{Table II Pre IPO incentive schemes}


incumbent executives and their "new" shareholders. It is at this point (i.e. at IPO) that it is reasonable to expect that companies may take the opportunity of the IPO to review their incentive pay strategy and begin to progress towards structures in line with those recommended by "best practice".

Following these changes nine companies in total operated conditional schemes (two of the three companies already having a conditional schemes plus seven companies newly adopting a conditional scheme) while 12 companies continued to operate unconditional schemes. Table III shows of the 22 companies with incentive pay pre IPO (all being executive share option schemes - ESOS), 15 companies replaced their original scheme with a new ESOS, while six companies continued to operate their existing schemes.

\section{Incentive pay schemes introduced at IPO for the first time}

In addition to the companies noted in section 1, a further 38 out of the 41 companies without incentive pay schemes pre IPO introduced such schemes at the time of (or immediately prior to) going public. Of those implementing their initial incentive pay scheme, 37 companies chose to introduce executive share option schemes only, whilst one company implemented an ESOS and LTIP scheme. Only three companies chose not to introduce an incentive pay scheme.

As can be seen from Table IV, a small majority of companies chose to introduce an unconditional scheme rather than a conditional one.

Combining the data contained in Tables III and IV, 59 (94 per cent) of the 63 companies had incentive pay immediately after the IPO, with four companies having more than one scheme running in tandem. Table $V$ shows the overall post IPO summary for all 59 companies with incentive pay and the fact that four companies have no incentive pay schemes post IPO.

Whilst it is encouraging to see that most companies do have incentive pay schemes following their flotation, it is the minority (26 companies) that have conditional schemes that can be seen to help promote the alignment of executive and shareholder interests by the imposition of performance targets linked to increasing shareholder value. The majority, as yet, have not chosen to take up the "best practice" recommendation of the Greenbury Report (1995) and ABI guidelines.

\section{Table III Companies with incentive pay pre IPO and their changes to schemes at IPO}

Description

Number

Continuation of original unconditional ESOS

Termination of original unconditional ESOS and introduction of new unconditional ESOS

Termination of original unconditional ESOS and introduction of new conditional ESOS

Continuation of original conditional ESOS

Termination of original conditional ESOS and introduction of new conditional ESOS

Termination of original conditional ESOS - not replaced

Total

5

7

7

\section{Table IV Companies implementing incentive pay for the first time at IPO}

Description

Number

Executive share option scheme (unconditional)

Executive share option scheme (conditional)

Executive share option scheme (conditional) and long term incentive plan (conditional)

Total 
Table V Incentive pay post IPO - the overall position

Companies without incentive pay schemes

Companies with ESOS (conditional) and LTIP (conditional)

Companies with ESOS (conditional)

Companies with ESOS (unconditional)

Total

\section{Performance evaluation}

Inspection of incentive pay schemes and their performance criteria shows that conditional schemes have three interrelated elements, a performance measure, a comparator and a performance target; and operate over a specified time period, typically three years (Pass et al., 2000).

Various performance measures are available, including "earnings per share" (EPS)[1], "total shareholder return" (TSR)[2] etc. (see Table VI). Ideally, any performance measure set by a company will be simple for both executives and investors to understand, provide a balance between the results for shareholders and factors that are within the control of the executives and should be correlated to the creation of shareholders value if the scheme is seen to be an attempt to align the executives motivation with those of the shareholders. There are two main issues to consider when deciding upon a performance measure, namely whether it should be accounts based or stock market based. It is generally considered that EPS is more accounts based, reflecting profitability, whilst TSR is stock market based.

A performance measure in isolation is of little significance and needs to be put into perspective by comparing it to some other financial yardstick. Again, various comparators can be utilised, including a comparison with the company's own previous financial performance as against some external benchmark, for example, the "retail price index" (RPI) or the performance of a "peer group" of other companies etc. (see Table VII).

Finally, a specified, quantitative performance target level is required in order to judge whether performance aspirations have actually been achieved, and hence option and LTIP grants to the executive can then be "exercised" (that is "cashed in").

Selecting an appropriate target level can be controversial. Performance may be judged against the company's own self-selected target (for example, a requirement that the company's own EPS growth over the next three years must be at least equal to that of the previous three years growth), or an external comparator/target may be used, for example a requirement that the company's EPS growth must exceed the increase in the RPI by at lease 6 per cent over a three-year period (see Table VIII). Either way companies often find themselves criticised for setting targets, which are too easily achieved (see below). This can

Table VI Performance measures for ESO schemes and the LTIP

Conditional option schemes

Number

Earnings per share (EPS)

Individual executive basis

Profit before interest and taxation (PBIT)

Share price

Share price and revenue growth

Not stated

Total

LTIP

Earnings per share (EPS) 
Own earnings per share (EPS)

Individual executive basis

Own PBIT

Own share price

Retail price index (RPI)

FTSE peer group of companies and RPI

Not stated

Total

LTIP

Retail price index

Table VIII Performance measures, comparators and targets for ESO schemes and the LTIP

\begin{tabular}{|c|c|c|c|}
\hline $\begin{array}{l}\text { No. of } \\
\text { companies }\end{array}$ & Measure & Comparator & Target (all over three years unless otherwise stated) \\
\hline 1 & EPS & Own EPS & To have eps $>0.001 p$ (in year of IPO, EPS was $-8.14 p$ ). \\
\hline 1 & EPS & Not stated & Not stated \\
\hline 5 & EPS & $\mathrm{RPI}$ & $\begin{array}{l}+0 \% \text { i.e. just exceed RPI } \\
+2 \% \\
+5 \% \\
+5 \% \\
+8 \%\end{array}$ \\
\hline 4 & $\begin{array}{l}\text { Individual executive } \\
\text { basis }\end{array}$ & $\begin{array}{l}\text { Individual executive } \\
\text { basis }\end{array}$ & Individual executive basis \\
\hline 3 & PBIT & Own PBIT & $\begin{array}{l}>£ 400,000 \text { by } 2 \text { years (at IPO company had not made a } \\
\text { profit and in year of IPO made loss of } £ 226,000 \text { ) } \\
>£ 700,000 \text { by } 1 \text { year after IPO }>£ 2 m \text { by } 2 \text { years after IPO } \\
\text { (in year of IPO PBIT was } £ 960,000 \text { ) } \\
>£ 0 \text { (made loss of } £ 99,000 \text { in year of IPO) }\end{array}$ \\
\hline 1 & PBIT & Not stated & Not stated \\
\hline 3 & Share price & Own share price & $\begin{array}{l}\text { Own share price }>50 p \text {. (the issue price for this share was } \\
25 p \text { ) } \\
\text { Own share price }>100 p \text { (the issue price for this share was } \\
50 p \text { ) } \\
\text { Own share price to increase by } 15 \% \text { pa }\end{array}$ \\
\hline 1 & Share price & FTSE peer group and RPI & $\begin{array}{l}\text { Exceed average growth of FTSE Support Services Sector } \\
\text { (peer group) and RPI }+10 \%\end{array}$ \\
\hline 1 & $\begin{array}{l}\text { Share price and revenue } \\
\text { growth }\end{array}$ & Not stated & Not stated \\
\hline $\begin{array}{l}6 \\
26 \\
\text { LTIP }\end{array}$ & Not stated & Not stated & Not stated \\
\hline 1 & EPS & RPI & $\begin{array}{l}+10 \% \text { to }+20 \% \text { straight line sliding scale from } 0 \text { to } 100 \% \\
\text { between the two values }\end{array}$ \\
\hline
\end{tabular}

be even harder to assess for the IPO company, which may not have years of trading data to realistically base future targets on.

A typical example of the performance evaluation process is provided by one of the survey companies:

At the present time the Directors consider growth in earnings per share to be a suitable measurement of the Company's performance and so in the foreseeable future an option granted under the Share Option Scheme will only be exercisable, if over a three year period following the grant of the option the Company achieves growth in its earnings per share which exceeds the growth in the Retail Prices Index by an average of two per cent per year (Capcon Holdings Plc Prospectus, p. 46). 
Table VI provides details of the performance "measures" used by the 26 IPO companies which now operate conditional incentive schemes, comprising those companies with conditional option schemes and the one company with both a conditional option scheme and a LTIP (composite details are provided in the Appendix).

The EPS measure predominates, followed by "share pricerdquo; and "profit before interest and taxation". In four other cases executives' performance is measured on an "individual basis". The most disappointing feature is the lack of disclosure of the performance measures employed by six of the companies.

Table VII presents details of the "comparators" which have been selected by the 26 IPO companies. It will be noted that internal comparisons predominate - "own share price", "own profit before interest and taxation", "own individual executive performance" and "own EPS" in the case of 11 companies. The RPI is the main external comparator. Again a lack of disclosure and transparency is evident with nine companies failing to reveal their comparators.

As noted above, the achievement of specific performance "targets" is required in order to enable executives to exercise their options and LTIP awards. The actual target levels set are thus crucial in this regard. Target levels may be relatively undemanding or they may be stretching. For example a requirement that EPS growth must exceed the increase in the RPI by 4 per cent over three years is more easily achieved than a figure of +9 per cent. Whilst this may be difficult for the IPO company to assess, many mature companies have been criticised by investors for setting an "easy" threshold target for their incentive schemes and have subsequently set tougher target levels (Pass, 2003). Comparing the degree of difficulty in achieving performance targets for schemes which have the same performance measures and comparator but which have different target levels is straightforward. More problematic, however, are inter-scheme comparisons, having different measures and comparators. For example, how does one compare the degree of difficulty of two schemes one of which requires EPS growth to exceed the increase in RPI by 4 per cent over three years with that of a scheme which requires the company's share price growth to exceed that of the average share price growth of a "peer group" of companies?

Table VIII combines together the performance measures and comparators present in Table VI and VII and adds in the performance "target" requirements which need to be achieved in order to trigger the exercise of options and LTIP grants for the 26 companies. The IPO companies operate a variety of schemes and as such it is not possible to make definitive performance comparisons although some general observations spring to mind (see concluding section).

Seven companies specified EPS growth targets comparing their EPS growth values against RPI values, while a further company incorporates this requirement alongside a share price growth target. Two companies settled for an undemanding EPS/RPI +0.1 per cent and 2 per cent, through +5 per cent in two further cases to a more taxing +8 per cent in the case of one company. One company merely required its EPS to become positive after a previous run of losses.

Four companies specified share price targets. Three of the companies looked to improvements in their own share price on a stand alone basis, while one company required its share price to exceed the average share price increase achieved by a peer group of companies. In the former case the performance target can be seen as "challenging": two companies required that their share price increase by 100 per cent, and the other by at least 45 per cent over three years.

Three companies specified as performance targets their own profit return (before interest and taxation), one merely requiring a turn round into profitability after previous losses, with the other two companies setting quantitative profit growth benchmarks. Four companies have set targets relating to the performance of individual executives. This is very much a "subjective" exercise. 
Finally we come back (again) to a major omission, nine of the companies surveyed failed to disclose their performance targets at the time of IPO and inspection of later Annual Reports reveals this still to be the case (see earlier comments).

\section{Concluding remarks}

This paper has focused on the changes in incentive pay schemes of a sample of 63 companies, some of which already operated such schemes, and others which adopted incentive pay schemes for the first time on the occasion these companies converted to "public" status through an IPO in 2001. The transition from "private" to "public" company represents a major landmark in a company's evolution and the infusion of "outside" shareholders brings with it new corporate governance responsibilities. The need to provide mechanisms which align the interests of the company's executives with those of its shareholders has been highlighted by various reports on corporate governance issues (in particular Cadbury (1992) and Greenbury (1995)) and which has found practical expression in the "Combined Code" of the London Stock Exchange.

One such mechanism is the executive incentive pay scheme embracing both conditional option and LTIP configurations with each requiring the achievement of specific performance "targets", and which if achieved, provide mutual benefits for both executives and shareholders. The presumption underlying this study is that with the dilution of ownership and control there will be the implementation of incentive pay schemes.

Interestingly, even prior to IPO one third of the companies in the sample had incentive pay schemes in place, albeit all but three of which were unconditional. This may seem surprising given the fact that the founding owner was also a key executive director of the company. In such circumstances the potential principal-agent conflict should not materialise since the interests of the owner (as "principal") and executive (as "agent") are one and the same. However, even in these cases the use of incentive pay schemes for other executive directors could be seen as important as an inducement in attracting high calibre executives to the Board, as a means of encouraging loyalty and commitment to the company and to reward their efforts over and above basic salary by giving them a stake in the growing prosperity of the business.

An important consideration at IPO, however, we would argue, is that companies should be concerned to have incentive pay schemes in place. The IPO nature of the data does mean that many of these companies do not have to fully comply with the Combined Code. This is only applicable to companies listing on the main market (the official list). Many of the new listings reflect the growing trend to float on the Alternative Investment Market (AIM) and thus do not have the need to comply with the Combined Code. However, they are still subject to agency theory and it is our opinion that the guidelines for AIM flotation do not emphasis strongly enough the importance of "best practice" for public companies and the influence that incentive pay schemes can have as a governance tool. This may explain the more relaxed nature of implementing unconditional rather than conditional schemes.

Not withstanding this, companies with performance targets are able to send a much stronger "strategic signal" to prospective investors (i.e. shareholders) that they will be particularly mindful of their responsibilities to protect and enhance the interests of shareholders and thus provide better future returns for shareholders than those companies without such schemes. With the flotation marketplace, it may be much more important to gain the "right" investors at this uncertain time and period of potential growth.

As noted earlier, the 63 companies included in this survey for 2001 are part of a broader based study of IPO companies over an extended time period. Until this data set is complete and more information is forthcoming, for example, on performance outcomes it is not possible to undertake definitive testing of the impact of conditional incentive pay schemes. Some preliminary observations based on the 2001 sample, however can be made. A substantial number of companies chose to change to or implement for the first time, a conditional executive incentive pay scheme, thus conforming to recommended "best"

VOL. 6 NO. 22006 | CORPORATE GOVERNANCE | PAGE 157 
corporate governance practice. To summarise, 22 companies operated incentive pay schemes prior to IPO of which only 3 had conditional schemes specifying performance targets. The remainder operated unconditional schemes. More notably, 41 companies had no incentive pay arrangements. Post IPO the situation had changed significantly with a total of 59 out of a total of 63 now operating incentive pay schemes, with 26 companies operating conditional schemes and 33 operating unconditional schemes.

Although the jump from three to 26 companies operating conditional incentive pay schemes may appear to be impressive, there is still a long way to go to conform to "best practice". Post IPO a majority of companies operated an unconditional scheme rather than a conditional one imposing specific performance targets.

Even in the case of those companies which adopted a conditional option scheme, there remain a number of question marks. First, many of the performance "targets" appear to be undemanding and will need to be made "tougher" in order to satisfy investor bodies such as the National Association of Pension Funds and the Association of British Insurers, which look to, for example, an EPS/RPI +9 per cent over three years as a minimum yardstick.

Second, the "preference" of 11 companies to use there "own" rather than external comparators is, in the eyes of some critics, too introverted and myopic. A more objective "test" of performance is to compare your performance against some other external comparator rather than one's own previous performance, since the former gives some indication of relative performance. Ideally it is argued, the comparator should be a "peer" group of other companies in the same line of business activity. This would enable investors to judge whether the company's performance was mediocre or truly excellent. Only one company in the survey used the "peer" group comparator at IPO. Some others used the RPI as their comparator but, it could be argued, testing one's performance against an all embracing inflation yardstick is not as demanding as doing well in comparison to competitor companies.

Third, in a substantial number of cases a big problem is the lack of transparency and disclosure. At IPO in 2001, nine of the 26 companies using conditional schemes had failed to fully reveal their performance criteria and this has remained the case (as at end of 2003). Clearly this is an unsatisfactory situation and undoubtedly shareholders will bring pressure to bear on this matter, particularly if this continues following the new disclosure amendments required by the 2002 Regulation. Similarly, an element of shareholder dissent may be directed at those schemes that are "unconditional" or where selected performance targets appear to be undemanding.

\section{Notes}

1. EPS is defined as total profit after tax divided by the number of ordinary shares.

2. TSR is defined as the return on an investor's shareholding reflected in the company's share price, assuming all dividends are reinvested.

\section{References}

ABI (1993), The Role and Duties of Directors: A Statement of Best Practice, Association of British Insurers, London.

ABI (1994), Long-term Remuneration for Senior Executives, Association of British Insurers, London.

ABI (1995), Share Options and Profit Sharing Incentive Schemes, (Amended June 1999), Association of British Insurers, London.

ABI (1999), Share Incentives: A Statement of Principles, Association of British Insurers, London.

ABI (2002), Executive Compensation and Share Based Remuneration: Guidelines for Share Incentive Schemes, Association of British Insurers, London.

Baker, M. and Gompers, P. (2003), "The determinants of board structure at the initial public offering", Journal of Law and Economics, Vol. 46 No. 2, pp. 569-98. 
Beatty, R. and Zajac, E. (1994), "Managerial incentives, monitoring and risk bearing: a study of executive compensation, ownership, and board structure in initial public offerings", Administrative Science Quarterly, Vol. 39 No. 2, pp. 313-35.

Berkema, H., Geroski, P. and Schwalbach, J. (1997), "Managerial compensation, strategy and firm performance", International Journal of Industrial Organization, Vol. 15 No. 4, pp. 413-6.

Berle, A. and Means, G. (1932), The Modern Corporation and Private Property, Macmillan, New York, NY.

Cadbury, A. (1992), Report of the Committee on Financial Aspects of Corporate Governance (Cadbury Committee Report), Gee Publishing, London.

Certo, S., Covin, J., Daily, C. and Dalton, D. (2001), "Wealth and the effects of founder management among IPO-stage new ventures", Strategic Management Journal, Vol. 22 Nos 6-7, pp. 641-58.

Conyon, M.J. (2000), Directors Pay in UK Plcs. A Guide to Executive Pay Determination, Chartered Institute of Personnel and Development, London.

Conyon, M.J., Peck, S., Read, L. and Sadler, G. (2000), "The structure of executive compensation contracts: UK evidence", Long Range Planning, Vol. 33 No. 4, pp. 478-503.

(The) Directors' Remuneration Report Regulations 2002 (2002), HMSO, London.

Fama, E.F. (1980), "Agency problems and the theory of the firm", Journal of Political Economy, Vol. 88 No. 8, pp. 288-307.

Fama, E.F. and Jensen, M. (1983), "Separation of ownership and control", Journal of Law and Economics, Vol. 26, pp. 327-49.

Greenbury, R. (1995), Director's Remuneration Report of a Study Group Chaired by Sir Richard Greenbury (Greenbury Report), Gee Publishing, London.

Hampel, R. (1998a), Committee on Corporate Governance: Final Report (Hampel Committee Report), Gee Publishing, London.

Hampel, R. (1998b), Committee on Corporate Governance: The Combined Code, Gee Publishing, London.

Hermlain, B. and Weisbach, M. (1991), "The effects of board composition and direct incentives on firm performance", Financial Management, Vol. 20 No. 4, pp. 101-12.

Jensen, M. and Meckling, W. (1976), "Theory of the firm: managerial behavior, agency costs and ownership structure", Journal of Financial Economics, Vol. 3 No. 4, pp. 305-60.

Murphy, K. (1985), "Corporate performance and managerial remuneration: an empirical study", Journal of Accounting and Economics, Vol. 7 Nos 1-3, pp. 11-42.

Pass, C. (2003), "Long-term incentive schemes, executive remuneration and corporate performance: an empirical study", Corporate Governance, Vol. 3 No. 4, pp. 18-27.

Pass, C., Robinson, A. and Ward, D. (2000), "Performance criteria of corporate option and long-term incentive plans: a survey of 150 companies 1994-1998", Management Decision, Vol. 38 No. 2, pp. 130-7.

Zajac, E. and Westphal, J. (1994), "The costs and benefits of incentives and monitoring in the largest US corporations: when is more not better?", Strategic Management Journal, Vol. 15, pp. 121-42. 
Table Al Companies with conditional ESO schemes post IPO

\begin{tabular}{|c|c|c|c|c|c|}
\hline IPODATE & Company & Industry & $\begin{array}{l}\text { Option } \\
\text { performance } \\
\text { measure }\end{array}$ & $\begin{array}{l}\text { Option } \\
\text { performance }^{\text {comparator }^{a}}\end{array}$ & $\begin{array}{l}\text { Option performance target (over } \\
\text { three years unless otherwise } \\
\text { stated) }\end{array}$ \\
\hline 31-May-01 & Capcon Holdings & $\begin{array}{l}\text { Speciality and } \\
\text { other finance }\end{array}$ & EPS & $\mathrm{RPI}$ & Growth of RPI $+2 \%$ per year \\
\hline 4-Jul-01 & Corac Group & $\begin{array}{l}\text { Engineering and } \\
\text { machinery }\end{array}$ & EPS & Not stated & Not stated \\
\hline 9-Apr-01 & $\begin{array}{l}\text { Marlborough Stirling } \\
\text { PLC }\end{array}$ & $\begin{array}{l}\text { Software and } \\
\text { computer } \\
\text { services }\end{array}$ & EPS & RPI & $\begin{array}{l}\text { RPI }+5 \% \text { pa compounded } \\
\text { exercisable in two equal tranches } \\
\text { after } 2 \text { years and } 3 \text { years, lapse } \\
\text { after } 6 \text { years }\end{array}$ \\
\hline 30-Nov-01 & Murgitroyd Group & Support services & EPS & $\mathrm{RPI}$ & $\begin{array}{l}\text { Growth to exceed RPI + 0\% per } \\
\text { year }\end{array}$ \\
\hline 30-Nov-01 & $\begin{array}{l}\text { Symphony Plastic } \\
\text { Technologies PLC }\end{array}$ & Chemicals & EPS & Own EPS & $\begin{array}{l}\text { Greater than } 0.001 \mathrm{p} \text { per share } \\
\text { exercisable after } 2 \text { years lapse } \\
\text { after } 10 \text { years }\end{array}$ \\
\hline 23-Feb-01 & Tribal Group & Support services & EPS & RPI & $\begin{array}{l}\mathrm{RPI}+8 \% \text { over } 2 \text { year period from } \\
\text { grant }\end{array}$ \\
\hline 4-Jun-01 & Atlantic Global & $\begin{array}{l}\text { Software and } \\
\text { computer } \\
\text { services }\end{array}$ & EPS & $\mathrm{RPI}$ & $\begin{array}{l}\text { EPS increase by RPI }+5 \% \text { from } \\
2000 \text { to } 2003\end{array}$ \\
\hline 23-Aug-01 & $\begin{array}{l}\text { MOS International } \\
\text { PLC }\end{array}$ & Oil and gas & $\begin{array}{l}\text { Individual } \\
\text { executive basis }\end{array}$ & $\begin{array}{l}\text { Individual } \\
\text { executive basis }\end{array}$ & Individual executive basis \\
\hline 21-Feb-01 & Oystertec & $\begin{array}{l}\text { Engineering and } \\
\text { machinery }\end{array}$ & $\begin{array}{l}\text { Individual } \\
\text { executive basis }\end{array}$ & $\begin{array}{l}\text { Individual } \\
\text { executive basis }\end{array}$ & $\begin{array}{l}\text { Individual executive basis } \\
\text { exercisable after } 2 \text { years lapse } \\
\text { after } 10 \text { years }\end{array}$ \\
\hline 15-Aug-01 & $\begin{array}{l}\text { Sport Entertainment } \\
\text { and Media Group PLC } \\
\text { (The) }\end{array}$ & $\begin{array}{l}\text { Media and } \\
\text { photography }\end{array}$ & $\begin{array}{l}\text { Individual } \\
\text { executive basis }\end{array}$ & $\begin{array}{l}\text { Individual } \\
\text { executive basis }\end{array}$ & Individual executive basis \\
\hline 10-Dec-01 & TripleArc PLC & $\begin{array}{l}\text { Media and } \\
\text { photography }\end{array}$ & $\begin{array}{l}\text { Individual } \\
\text { executive basis }\end{array}$ & $\begin{array}{l}\text { Individual } \\
\text { executive basis }\end{array}$ & $\begin{array}{l}\text { Individual executive basis: } \\
\text { exercisable on two triggers relatec } \\
\text { to specific sales and/or profit } \\
\text { targets }\end{array}$ \\
\hline 26-Feb-01 & Blavod Black Vodka & Beverages & Not stated & Not stated & Not stated \\
\hline 28-Jun-01 & $\begin{array}{l}\text { GW Pharmaceuticals } \\
\text { PLC }\end{array}$ & Pharmaceuticals & Not stated & Not stated & Not stated \\
\hline 11-Sep-01 & $\begin{array}{l}\text { Henderson Morley } \\
\text { PLC }\end{array}$ & Pharmaceuticals & Not stated & Not stated & Not stated \\
\hline 25-Oct-01 & $\begin{array}{l}\text { Home Entertainment } \\
\text { Corporation PLC }\end{array}$ & General retailers & Not stated & Not stated & Not stated \\
\hline 26-Mar-01 & Real Affinity & $\begin{array}{l}\text { Media and } \\
\text { photography }\end{array}$ & Not stated & Not stated & Not stated \\
\hline 20-Aug-01 & $\begin{array}{l}\text { SRS Technology } \\
\text { Group }\end{array}$ & $\begin{array}{l}\text { Household goods } \\
\text { and textiles }\end{array}$ & Not stated & Not stated & Not stated \\
\hline 23-May-01 & $\begin{array}{l}\text { Imprint Search \& } \\
\text { Selection }\end{array}$ & Support services & PBIT & Not stated & Not stated \\
\hline 14-May-01 & $\begin{array}{l}\text { Maverick } \\
\text { Entertainment Group }\end{array}$ & $\begin{array}{l}\text { Media and } \\
\text { photography }\end{array}$ & PBIT & Own PBIT & $\begin{array}{l}\text { PBIT in yr ending } 21-\mathrm{Dec}-03 \text { is } \\
\text { equal or greater than } £ 400,000\end{array}$ \\
\hline 17-May-01 & $\begin{array}{l}\text { Proactive Sports } \\
\text { Group }\end{array}$ & $\begin{array}{l}\text { Media and } \\
\text { photography }\end{array}$ & PBIT & Own PBIT & $\begin{array}{l}\text { PBIT in yr ending 31Aug-01 } \\
>£ 700,000 \text { and yr ending } 2002 \\
>£ 2 m\end{array}$ \\
\hline 14-Feb-01 & Staffing Ventures & Support services & PBIT & Own PBIT & $\begin{array}{l}\text { Previous } 6 \text { months figs are positive } \\
\text { options exercisable from any time } \\
\text { performance criteria met and lapse } \\
\text { after } 10 \text { years }\end{array}$ \\
\hline
\end{tabular}

(Continued) 


\section{Table Al}

\begin{tabular}{|c|c|c|c|c|c|}
\hline IPODATE & Company & Industry & $\begin{array}{l}\text { Option } \\
\text { performance } \\
\text { measure }\end{array}$ & $\begin{array}{l}\text { Option } \\
\text { performance }^{\text {comparator }^{a}}\end{array}$ & $\begin{array}{l}\text { Option performance target (over } \\
\text { three years unless otherwise } \\
\text { stated) }\end{array}$ \\
\hline 5-Jul-01 & LiDCO Group PLC & Health & Share price & Own share price & $\begin{array}{l}\text { Share price to have } 15 \% \text { growth pa } \\
\text { over three years = 33\% vest, full } \\
\text { vesting } 22.5 \% \text { growth }\end{array}$ \\
\hline 14-Aug-01 & Meriden Group PLC & Support services & Share price & Own share price & $\begin{array}{l}\text { Share price to be greater } \\
\text { or }=50 p\end{array}$ \\
\hline 22-Mar-01 & Patientline & Telecom. services & Share price & $\begin{array}{l}\text { FTSE peer group } \\
\text { of companies and } \\
\text { RPI }\end{array}$ & $\begin{array}{l}\text { Exceed average growth of FTSE } \\
\text { support services sector and RPI } \\
+10 \%\end{array}$ \\
\hline 23-May-01 & Pursuit Dynamics & $\begin{array}{l}\text { Engineering and } \\
\text { machinery }\end{array}$ & Share price & Own share price & $\begin{array}{l}\text { Share price greater than } 100 p \text { for } \\
\text { period of } 30 \text { consecutive days } \\
\text { options exercisable in three equal } \\
\text { tranches after } 1,2 \text { and } 3 \text { years }\end{array}$ \\
\hline 8-Jan-01 & Intercede Group & $\begin{array}{l}\text { Software and } \\
\text { computer } \\
\text { services }\end{array}$ & $\begin{array}{l}\text { Share price and } \\
\text { rev growth }\end{array}$ & Not stated & Not stated \\
\hline \multicolumn{6}{|l|}{ LTIP } \\
\hline 23-Feb-01 & Tribal Group & Support services & EPS & $\begin{array}{l}\mathrm{RPI}+10 \% \text { to } \mathrm{RPI} \\
+20 \% \text { on straight } \\
\text { line basis }\end{array}$ & $\mathrm{RPI}$ \\
\hline
\end{tabular}

Note: ${ }^{a}$ some companies have indicated that schemes will be amended to reflect the Consumer Price Index (adopted December 2003) rather than RPI for grants following this date

\section{Corresponding author}

Deborah Allcock can be contacted at: d.allcock@ bradford.ac.uk

To purchase reprints of this article please e-mail: reprints@emeraldinsight.com Or visit our web site for further details: www.emeraldinsight.com/reprints 